\title{
Science and Skill Acquisition in Junior Secondary School in Ekiti State, Nigeria
}

\author{
Prof. Jegede, Samuel Akingbade \\ Department of Science Education, Faculty of Education, Ekiti State University, \\ Ado Ekiti, Ekiti State, Nigeria \\ Adegbola, Funmi Florence Ph.D* \\ Department of Science Education, Faculty of Education, Ekiti State University, \\ Ado Ekiti, Ekiti State, Nigeria
}

\begin{abstract}
This study examined science and skill acquisition in junior Secondary Schools in Ekiti State, Nigeria. The study adopted the descriptive research of the survey type. Participants were 240 science-oriented youths randomly selected from six states across six geopolitical zones in Nigeria. Three instruments titled "Problem of Unemployment in your Locality Questionnaire" (PUYLQ), "Skill Acquisition Programme Questionnaire" (SAPEQ) and "Security Challenges Questionnaire" (SCQ) were used to collect data for the study. The reliability of PUYLQ, SAPEQ and SCQ were determined through test and re-test method and these yielded a correlation coefficient of $0.87,0.85$ and 0.89 , respectively at 0.05 level of significance. Two-way Analysis of Variance (ANOVA) was used to analyze the data. The finding revealed that employment can significantly influence level of skill acquisition programme among science based students in Nigeria. The finding also revealed that gender has no significant influence on level of skill acquisition programmes among science-based students. The study revealed that employment status and level of skill acquisition can significantly influence security challenges in Nigeria. It was recommended that government should provide employment for the science based graduates for national development. Government should also engage the jobless science based graduates with skill acquisition programmes to reduce social vices in the country. It was also recommended that, there should be no gender disparity while creating employment for science based students. In addition, both male and female Science graduates should give opportunity for participating in skill acquisition programmes for national development.
\end{abstract}

Keywords: National development, Skill acquisition programmes, Science Graduates, Employment/job opportunities, Insecurity.

DOI: $10.7176 / \mathrm{JEP} / 12-8-06$

Publication date:March $31^{\text {st }} 2021$

\section{Introduction}

Science is the embodiment of intellectual and practical activity which involves the systematic way of studying the structure and behaviour of the physical and natural world through observation and experimentation (Advanced English Dictionary 2006). Science helps man to use his knowledge in solving problems around him. Man also uses his knowledge to invent things which are valuable to him and the world at large. The role of science to man cannot be over emphasized. Hence, man needs to exercise himself by putting efforts to which ever choices he has made in other to survive in his environment. Science graduates in Nigeria are full of knowledge and they are supposed to put their knowledge into valuable use. To curb some of the evil vices among the youths in the country which contributed to the nation challenges, science based students should be engaged properly either by employment or skills acquisition programmes around them.

The state of insecurity in Nigeria is growing very enormously every day due to the rate of unemployment among the youths in the country. The situation is giving almost everyone in the country a nightmare. Unemployment as described by the International Labour Organization (2019) is the availability of the labour force that is without work and seeking employment. This group further described unemployment as when people are without jobs and are in search of it for about five weeks without securing any. In the same vein, Nwamanah (2018) reiterated that unemployment arises as a result of insufficient and non- availability of jobs to correspond with the growing population. Nigeria's population is growing daily and tension is on the increase as the evil vices committed by the unemployed youths daily increase. Employment is the act of given a contract which attracts the payment of salary by the employer to the employee. Many youths are engaged in armed robbery, kidnapping, cybercrime, political thuggery, among others. Violence through various groups of terrorists such as Fulani Jihadists, Boko haram among others in the recent years also serves as a major cause of insecurity in the country. This has created fear in the heart of foreigners who have come to partner with Nigeria for laudable businesses. For this reason, many expatriates have vacated the country. This is a big challenge to the nation's development.

Nigeria is blessed with diverse resources human and materials; yet, unemployment and insecurity still remain as major challenges to National development. National development according to Bawa (nd) connotes the process 
of restructure and development of individuals and nation in various dimensions of life. Nigeria government is supposed to introduce the means to restructure and develop individuals especially, the physical, human resources, knowledge and skill that can affect the total aspects of all citizens. This seems to embrace the full- growth and expansion of industries, agriculture, and education, social, religious, political, cultural, scientific and material in the nation. The study of (Bawa nd) affirmed National development supposed to affect the total aspects of all citizens such as physical, human resources, knowledge and skill. Therefore, various facilities such as skill acquisition, human resources, incentive inform of cash and materials should be provided to meet the aspirations of disadvantaged science - based graduates in order to contribute positively to Nations development. Unfortunately, Science-based graduates seem to be deprived of the necessary supports and thereby constitute nuisance in the streets committing different crimes.

However, Nigeria science based students need to put voluntary efforts in any field to survive in their environment. Ekong and Ekong (2016) noted that unemployment is traceable to the time of oil boom of 1970s when the Nigerian government and individuals abandoned skill acquisition programmes and also failed to utilize diversified entrepreneurship practices which have capacity to improve the country's economy and individual. History revealed that before the oil boom, Nigerian citizens were able to engage themselves in different jobs which sustained them and then, educational system in Nigeria also gave room for craft practices which initiated many into skilled practices such as; Motor- technics, bricklaying, carpentry, block making among others. Unfortunately, things had changed drastically, as many people are no longer thinking of what other things to do than going to school to acquire certificates and using it to commit crime or becoming politicians so as to have access to the national cake.

Today, the nation is facing security challenges and political leaders have failed to provide lasting solutions to it. Finding a lasting solution to the issue of unemployment and insecurity can procure sustainable development for the nation's economy and lives of her citizenry. Furthermore, science - based graduates who are supposed to invent new things are roaming about the street contributing to the national security challenges. Government is unable to provide a lasting solution to this problem due to its insensitivity. Science- based graduates are unable to play their roles as scientists in the country. The school curriculum in the sciences is supposed to be drawn to include practical aspects of scientific knowledge rather than theoretical aspects only. This is supposed to give students ample opportunity to operate scientifically and provide job for them. Inability to give room for practice may have incapacitated these graduates and rendered them impotent in the area of production as the little knowledge gained theoretically cannot sustain them. This is why they must be pushed to the area of skill acquisition to develop themselves. The inability of the Nigeria government to put some of the factors of production which are idle into utilization to engage science- based youths has added to the problem facing the country.

The Nigerian government is supposed to encourage craft and agricultural practices so that citizens can be engaged in the production of craft products (such as; baskets, hats, mats) and planting of various crops (such as; cocoa, cotton, groundnut, oil palm, cassava, rubber) to feed industries. They are also expected to encourage skilled works (such as; carpentry, painting and auto-mechanic, among others) all of which could provide employment for the many science- based graduates roaming about the street or help them to establish science based business.

In the recent time, the new data released by the National Data Bureau of Statistics in Nigeria revealed the unemployment rate in 2018 as $33.10 \%$. This rate was also confirmed by the Minister of labour and employment who declared 36.50 percent in the year 2020. The NBS remarked that if $60 \%$ of the population is unemployed in a country, then there is unemployment. Since unemployment in Nigeria has gone beyond this percentage, therefore, seems to have resulted to threat to the development of the nation.

Rei and pilgrim as cited by Francis and Akanganngang (2012) noted that the large number of young graduates who enter the labour market each year but unable to secure employment or receive training resulted to poverty and poor economic condition of the nation. They remarked that this has added to economic costs in terms of gross domestic product gap and liable to result in social crime. Kruger (2004) opines that entrepreneurship begins with action and the creation of new jobs. The ways to proffer solution to the unemployment include the creation of jobs and empowerment to science graduates are through entrepreneurship skills, provision of access to capital and credit among others.

Skill acquisition is the process of training a group of people on a particular task in order to become an expert in it. In Nigeria, several reform programmes had been introduced to find lasting solution to the collapsed economic status of the youths in the past through many skill acquisition programme such as:

National Directorate of Employment (NDE), the Structural Adjustment Programme (SAP), Better life programme (BLP), National agency for poverty Eradication Programme (NAPEP), National Open Apprenticeship Scheme,Agricultural Sector Employment Programme, Subsidy Reinvestment and Empowerment programme (SUREP) among others.

The Nigerian government had been engaged in continuous struggle for socio- economic and political development which is believed can only be achieved through efficient and proactive indigenous manpower to serve as the propelling force for the national growth and development of citizens (Luciani, 2017). 
The National Directorate of Employment (NDE) was introduced in 1986 and launched formally in 1987. This programme was introduced with the intention of providing jobs for the youths in Nigeria and it covered all sectors of the nation's economy (Ekong and Ekong, 2016). According to these researchers, the work of the Directorate includes the acts of obtaining and maintaining a data bank which helps in declaring vacancies and employment available to reduce the cost on the search for job; instituting vocational acquisition training centers, training for rural employment skills, and entrepreneurial training, among others. NDE was able to introduce their programmes in all the 36 states of the Federation. Despite the introduction of all these programmes, Okafor (2018) remarked that a number of these skills which should be acquired appeared not to be available and functional to the youths in the country. Ogundele, Akingbade and Akinlabi (2012) reiterated that the contribution of skill acquisition through youth empowerment is much significant to nation's development. The economy of Nigeria's social and economy problems will be drastically reduced if they can be given adequate vocational training in skill, raw materials, machineries and equipment. (Ayorinde, Okeh, Balogun, Isuwa and Danlami 2017).

Skills acquisition programmes are capable of empowering large number of youths both male and female from different communities in Nigeria. But on the contrast, Amadi and Abdullah (2012) said a greater percentage of the youths are able to be developed in the programme successfully. Anyaegbu as cited by Okafor (2018) supported that a significant percentage of the apprenticeships were able to graduate in different areas of their specialization. The source also revealed that, the Development Education Centre (DEC) also provides business education for the youths to empower them with the knowledge and understanding needed to start a business in the face of tough economy such as we have in Nigeria. Akpama, Ezang, Asor, and Osang (2011) noted that acquisition of vocational skills contributes significantly to the reduction of unemployment among the science youths who were able to participate in the programme.

Despite the introduction of all these programmes, massive unemployment for the science graduates still remained a challenge to the development of the economy of the nation. The reason for this came up in the study of Ogunlela (2012), which reported that the impact of NDE on youths in Nigeria has not been particularly positive and much still need to be done. Thorough appraisal and overhauling of these programmes are supposed to be carried out for a positive result. There are many science youths parading the streets of Nigeria, causing lots of havoc due to lack of necessary skills and jobs to occupy them. The contribution of skill acquisition and training of the youths to reduce unemployment will be more significant if there could be improvement in the way of organizing the programme to meet the needs of science graduates at all levels in the country (Akpama et al. 2011).

\section{Problem of the study}

Problem of national development through skill acquisition programme for Science -based students has been observed by the researcher over the years. The researcher observed that the way the science -based graduates are roaming the street does not contribute to national development as this action does not motivate the learners to concentrate to their studies any longer, thereby contributing to social vices in the country. The human material engaged in skill acquisition especially science based graduates seem not available to contribute to the production of the nation's economy.

\subsection{Purpose of the study}

The purpose of this study is to examine how skill acquisition programme can contribute positively to sustainable national development in Nigeria. Specifically, the study sought the causes and fundamental effects of unemployment in Nigeria as well as to identify the challenges facing the youths in Nigeria.

\subsection{Research Hypotheses}

The following research hypotheses were tested at 0.05 level of significance.

1. Skill acquisition will not significantly influence national development in Nigeria.

2. Employment status will not significantly influence skill acquisition among Science-based graduates in Nigeria

3. Gender will not significantly influence level of skill acquisition among science -based graduates.

4. Employment status will not significantly influence development in Nigeria

\section{Methodology}

\subsection{Research Design}

The study adopted a descriptive research of the survey type to examine employment and skills acquisition programme as a panacea for sustainable national development in Nigeria. The design is suitable because it enabled the researcher to gather relevant information from science- based youths, using qualitative measure of survey.

\subsection{Sample and Sampling Procedure}

The sample for this study consisted of 240 science graduates who were randomly selected from the six geopolitical 
zones in Nigeria through the multi-stage sampling procedure. The first stage was the purposive selection of six states (Kaduna, Gombe, Enugu, Ekiti, Plateau and Delta) out of six zones in Nigeria. The second stage involved the use of simple random sampling techniques to select one local government area from each state, making a total of six Local Government Areas. Stage three involved the purposive selection of 40 graduates (male $=20$ female $=$ 20) from each of the selected local government areas (making a total of 240 graduates). In all, the total samples of 240 science based graduates were selected for the study.

\subsection{Research Instruments}

"Problem of Unemployment in your Locality Questionnaire" (PUYLQ), Skill Acquisition Programme Questionnaire (SAPEQ) and National Development Questionnaire (NDQ) were the instruments used to collect data for the study. The PUYLQ contained 20 structured items and was used to collect information about the problem of unemployment by the science- based graduates in their locality; SAPEQ contained 20 structured items and was also used to collect information about the skill acquisition operation in the state. The NDQ questionnaire contained 20 structured items and was used to collect information about security challenges facing youths in the state. These instruments were given to three experts in the Department of Social Sciences and Science Education and two experts in the area of Test, Measurement and Evaluation from Ekiti state university, Ado Ekiti for face and content validities respectively. Test- retest was used to determine the reliability of the instruments from which yielded reliability co-efficient of $0.87,0.85$ and 0.89 for PUYLQ, SAPEQ and NDQ, respectively.

\subsection{Administration of the Instrument}

The researcher and research assistants visited the local government headquarters in each state selected for the study for the administration of the instruments (PUYLQ, SAPEQ and NDQ). The instruments were jointly administered by the researcher and research assistants to the available science graduates selected for the study. The completed questionnaires were collected by the research assistants.

\section{Data Analysis}

The data collected were analyzed using inferential statistics of two way of analysis of variance (ANOVA).

Results

Hypothesis 1: Hypothesis 1: Skill acquisition programmes will not significantly influence national development in Nigeria

Table 1: Two-way Analysis of Variance (ANOVA) for skill acquisition on national development in Nigeria.

\begin{tabular}{|l|l|l|l|l|l|}
\hline Source & Sum of Squares & Df & Mean Square & F & Sig. \\
\hline Corrected Model & $1897.333^{\mathrm{a}}$ & 6 & 316.222 & 492.512 & .000 \\
\hline Intercept & 66383.691 & 1 & 66383.691 & 103391.712 & .000 \\
\hline Level of Skill Acquisition & 35.068 & 2 & 17.534 & 27.309 & .000 \\
\hline Level of Security Challenges & 1546.172 & 2 & 773.086 & 1204.071 & .000 \\
\hline Level of Skill Acquisition * Level of Security Challenges & 6.630 & 2 & 3.315 & 5.163 & .003 \\
\hline Error & 149.600 & 233 & .642 & & \\
\hline Total & $\mathbf{1 4 8 8 6 4 . 0 0 0}$ & $\mathbf{2 4 0}$ & & & \\
\hline Corrected Total & $\mathbf{2 0 4 6 . 9 3 3}$ & $\mathbf{2 3 9}$ & & & \\
\hline
\end{tabular}

a. $\mathrm{R}$ Squared $=.927$ (Adjusted R Squared $=.925$ )

Table 4 shows that the F- value of 5.163 is significant because the $P$ value $(0.003)$ is less than 0.05 at 0.05 level of significance. This implies that the null hypothesis is rejected. Hence, level of skill acquisition programmes significantly influenced development in Nigeria.

Hypothesis 2: Employment status will not significantly influence skill acquisition among Science- based graduates in Nigeria 
Vol.12, No.8, 2021

Table 2: Two-way Analysis of Variance (ANOVA) of influence of employment status on level of skill acquisition programmes among Science- based graduates.

\begin{tabular}{|l|l|l|l|l|l|}
\hline Source & Sum of Squares & Df & Mean Square & F & Sig. \\
\hline Corrected Model & $1743.052^{\mathrm{a}}$ & 5 & 348.610 & 190.648 & .000 \\
\hline Intercept & 75784.038 & 1 & 75784.038 & 41444.857 & .000 \\
\hline Employment Status & 1.551 & 1 & 1.551 & .848 & .358 \\
\hline Level of Skill Acquisition & 1526.389 & 2 & 763.194 & 417.377 & .000 \\
\hline Employment Status * Level of Skill Acquisition & 103.554 & 2 & 51.777 & 28.309 & .000 \\
\hline Error & 427.881 & 234 & 1.829 & & \\
\hline Total & $\mathbf{1 1 5 8 8 0 . 0 0 0}$ & $\mathbf{2 4 0}$ & & & \\
\hline Corrected Total & $\mathbf{2 1 7 0 . 9 3 3}$ & $\mathbf{2 3 9}$ & & & \\
\hline
\end{tabular}

a. $\mathrm{R}$ Squared $=.803$ (Adjusted R Squared $=.799$ )

Table 1 showed that the F- value of 28.309 is significant because the $P$ value $(0.000)$ is less than 0.05 at 0.05 level of significance. This implies that the null hypothesis is rejected. Hence, employment status significantly influenced skill acquisition programmes among Science- based graduates in Nigeria.

Hypothesis 3: Gender will not significantly influence skill acquisition programmes among Science- based graduates in Nigeria.

Table 3: Two-way Analysis of Variance (ANOVA) of influence of gender on skill acquisition programmes among Science- based graduates in Nigeria.

\begin{tabular}{|l|l|l|l|l|l|}
\hline Source & Sum of Squares & Df & Mean Square & F & Sig. \\
\hline Corrected Model & $1750.012^{\mathrm{a}}$ & 5 & 350.002 & 194.575 & .000 \\
\hline Intercept & 73605.210 & 1 & 73605.210 & 40918.867 & .000 \\
\hline Gender & 3.421 & 1 & 3.421 & 1.902 & .169 \\
\hline Skill Acquisition & 1651.784 & 2 & 825.892 & 459.133 & .000 \\
\hline Gender * Skill Acquisition & 1.510 & 2 & .755 & .420 & .658 \\
\hline Error & 420.921 & 234 & 1.799 & & \\
\hline Total & $\mathbf{1 1 5 8 8 0 . 0 0 0}$ & $\mathbf{2 4 0}$ & & & \\
\hline Corrected Total & $\mathbf{2 1 7 0 . 9 3 3}$ & $\mathbf{2 3 9}$ & & & \\
\hline
\end{tabular}

a. R Squared $=.806$ (Adjusted R Squared $=.802$ )

Table 2 shows that the $F$ - value of 0.420 is not significant because the $P$ value $(0.658)>0.05$ at 0.05 level of significance. This implies that the null hypothesis is not rejected. Hence, gender has no significant influence on level of skill acquisition programmes among science based youths.

Hypothesis 4: Employment status will not significantly influence nationa development in Nigeria.

Table 4: Two-way Analysis of Variance (ANOVA) of influence of employment status on National development.

\begin{tabular}{|l|l|l|l|l|l|}
\hline Source & Sum of Squares & Df & Mean Square & F & Sig. \\
\hline Corrected Model & $1865.193^{\mathrm{a}}$ & 5 & 373.039 & 480.305 & .000 \\
\hline Intercept & 76247.442 & 1 & 76247.442 & 98172.257 & .000 \\
\hline Employment Status & 17.156 & 1 & 17.156 & 22.090 & .000 \\
\hline Level of National Development & 1658.930 & 2 & 829.465 & 1067.976 & .000 \\
\hline Employment Status * Level of National Development & 9.196 & 2 & 4.598 & 5.920 & .003 \\
\hline Error & 181.741 & 234 & .777 & & \\
\hline Total & $\mathbf{1 4 8 8 6 4 . 0 0 0}$ & $\mathbf{2 4 0}$ & & & \\
\hline Corrected Total & $\mathbf{2 0 4 6 . 9 3 3}$ & $\mathbf{2 3 9}$ & & & \\
\hline
\end{tabular}

a. R Squared $=.911$ (Adjusted R Squared $=.909)$

Table 3 shows that the F- value of 5.920 is significant because the $P$ value $(0.003)$ is less than 0.05 at 0.05 level of significance. This implies that the null hypothesis is rejected. Hence, employment status significantly influenced development in Nigeria

\subsection{Discussion}

Findings revealed that, showed that skill acquisition programmes can significantly influence national development. Akpama etal (2011) revealed that acquisition of vocational skills contributes significantly to the reduction of 
unemployment among the science youths (male or female) who were able to participate in the skill acquisition programmes.

The study also showed that the employment status of science based graduates significantly influence skill acquisition among Science-based graduates in Nigeria. The study of Rei and pilgrim in Francis and Akanganngang (2012) supported that a large number of young people enter the labour market each year but are unable to secure employment. On the contrary, Dabalen et al. (2017) noted that the massive unemployment of the youths in Nigeria can be traceable to lack of essential employable skills by the youth themselves. The study also showed that gender has no significant influence on skill acquisition among science- based graduates. The study also showed that Science- based graduates should be empowered to reduce unemployment in the country. Ekong and Ekong (2016) supported that the provision of vocational skill acquisition and counseling services for the youth, promotes their attitude towards self and nations development.

\section{Conclusion and Recommendations}

It was concluded from the findings of this study that giving employment and engaging science -based graduates in skill acquisition will drastically influence national development of the nation.

The following recommendations were made based on these findings:

1. Science based graduates should be engaged in skill acquisition programmes relevant to their fields.

2. Government should help provide jobs for the science graduates to reduce massive unemployment and social vices in the nation.

3. More skill acquisition programmes which can engage large numbers of science -based graduates should be made compulsory for Science- based graduates who are yet to get job in the offices.

4. Science -based graduates should be empowered by giving them loan or other incentives to embark on business in their fields.

5. Science-based youths should be open to agricultural production.

6. Moreover, some of the factors of production which are idle should put into utilization by the sciencebased graduates as a part of source for skill acquisition to them.

\section{References}

Akpama, S.I., Esang, O. U.,Asor, L.J. \& Osang, W.O. (2011). "Non- formal Education Programmes and poverty Reduction among young Adults in southern Distict, cross river state, Nigeria". Journal of Education and development Psychology 1: 65-67.

Amadi, O.B \&A budullah, H.(2012). "Perception of capacity Building among youths involved in Vocational skills development". Journal of Social Science 3: 214-221.

Ayorinde, M.O, Okeh, B.I, Isuwa, E. \& Danlami, E. (2017). "Perceived influence of skill Acquisition center's towards job creation and poverty reduction among graduates in Kaduna State, Nigeria". ATBU Journal of Science, Technology and Education

Ekong, U.M., \& Ekong G, C. U (2016). Skill Acquisition and Unemployment Reduction in Nigeria: A case study of National Directorate of Employment (NDE) in Akwa Ibom State, International Journal of Economics and Management Sciences.

Francis \& Akanganngang, J. A.(2012). "Youth employment and Entrepreneurial Skills Development in the Ajumako-Enyan-Essiam District of Ghana”. Ghana Journal of Development Studies, 9 (1), 2012.

International Labour Organization (2019). ILOSTAT database. Data retrieved from https://www.indexmundi.com/facts/ind Kruger, M. E. 2004. Entrepreneurship theory and creativity Pretoria: University of Pretoria.

Kruger, M. E. (2004). Entrepreneurship theory and creativity Pretoria: University of Pretoria.

Luciani, G. (2017). Combining Economic and political Development: The experience of MENA, international Development Policy series 7

National Data Bureau of Statistics in Nigeria. (2018). Labour Force Survey. Abuja, NBS.

Nwamanah, D. (2018). "Problems of Security in Nigeria and Possible Solutions info Guide Nigeria.com./ information Guide in Nigeria". https:// infoguidenigeria.com/problems.

Ogundele, O.J.K, Akingbade, W.A. \& Akinlabi, H.B (2012). "Entrepreneurship Training and Education as strategic Tools for Poverty Allevation in Nigeria". America International Journal of Contemporary Research 2 148-156.

Ogunlela, Y. I. (2012). "Impact of the programmes of the National Directorate of Employment on Graduate Employment and Unemployment in Kaduna State of Nigeria". Pakistani Journal of Social Sciences 9, 40-45.

Okafor, C. F. (2018). "Science Education: A tool for skill acquisition and Entrepreneurship Development of Nigeria Students". Nnadiebube Journal of Education in Africa (NJEA) 3(2), 